\title{
Hormone and Metabolic Research: 50 Years of Research
}

\author{
Authors \\ Matthias Schott ${ }^{1}$, Stefan R. Bornstein ${ }^{2,3,4,5}$, Constantine A. Stratakis ${ }^{6}$
}

Affiliation

1 Division for Specific Endocrinology, University Hospital Duesseldorf, Duesseldorf, Germany

2 Department of Medicine III, University Hospital Carl Gustav Carus, Technische Universität Dresden, Dresden, Germany

3 Paul Langerhans Institute Dresden of Helmholtz Centre Munich at University Clinic Carl Gustav Carus of TU Dresden Faculty of Medicine, Technische Universität Dresden, DZD-German Centre for Diabetes Research, Dresden, Germany

4 Center for Regenerative Therapies, Technische Universität Dresden, Dresden, Germany

5 Diabetes and Nutritional Sciences Division, King's College London, London, UK

6 Section on Endocrinology and Genetics, Eunice Kennedy Shriver National Institute of Child Health and Human Development, Bethesda, MD, USA

received 10.12 .2018

accepted 17.12.2018
Bibliography

DOI https://doi.org/10.1055/a-0818-8930

Horm Metab Res 2019; 51: 8-10

(c) Georg Thieme Verlag KG Stuttgart · New York

ISSN 0018-5043

Correspondence

Matthias Schott, MD, PhD

Division for Specific Endocrinology

Medical Faculty

University of Düsseldorf

Moorenstraße 5

40225 Düsseldorf

Germany

Tel.: + 49/211/81 04860, Fax: +49/211/81 19218

Matthias.Schott@med.uni-duesseldorf.de
Dear Readers,

Hormone and Metabolic Research enters its $51^{\text {st }}$ year of publication and celebrates its Golden Anniversary this year in 2019. This is a significant landmark and key milestone and provokes reminiscence and deeper reflection of what has been done in the past.

Back in 1969, the journal was founded as Hormone and Metabolic Research - Hormon- und Stoffwechselforschung - Hormones et Métabolisme, reflecting the language issue in scientific publications in Europe at the time: English was well on its way to becoming the lingua franca of scientific discourse, but it had not arrived there yet. The journal accepted papers not only in English, but also in French and German! If the main paper was not written in English, an English summary had to be supplied. Still, the first ever editorial ( Fig. 1) was already written in English by the two editors-in-chief, Rachmiel Levine and Ernst F. Pfeiffer. Their aim in founding the journal is as essential today as it was then: in the face of an ever-growing body of scientific literature, how does one ensure that new, relevant and peer-reviewed data is made available as quickly as possible in a journal that satisfies the researchers' needs. Back in 1969, endocrinology and metabolism questions were spread across many titles, and it was the editor-in-chiefs ambition to "improve communication between clinicians and scientists [...], facilitate exchange of information between different countries" and to remedy the situation that "the scientific author is confronted with an unsatisfying market of journals to which his special (sic) manuscript might be profitably submitted." [1]
We can proudly proclaim that these initiatives have been successfully accomplished and the number of citations achieved by the papers in Hormone and Metabolic Research reflect the international importance of this journal and its aim to publish only work of the highest quality.

Over the past 50 years, HMR fulfilled these ambitions with great success. Under the editorship of such eminent scholars as Åke Lernmark, Werner A. Scherbaum and now with Stefan R. Bornstein, Matthias Schott and Constantine A. Stratakis, the journal became an international pillar of scientific research and discovery. This is not only reflected in a very stable impact factor, but also in the highly popular special topic issues that highlight and showcase the state of the art of the crucial endocrinological questions of today.

Over the last two decades we published more than 40 special topic issues, highlighting recent advances in endocrinology and metabolism. Important issues focused on metabolic syndrome, insulin resistance, bone metabolism, thyroid disorders, endocrine tumors and other issues. Within the last couple of years, a special focus was given to endocrine tumors, e. g. of the neuroendocrine system including pituitary tumors and pheochromocytoma / paraganglioma. In addition, three issues were published on primary hyperaldosteronism focusing on the genetic cause of the disease as well as diagnostic and therapeutic options [2-15].

Most recently, we also focused on thyroid diseases, e. g. autoimmune thyroid disease; here another three special issues were published highlighting the genetic cause as well as the immunological background, diagnostic procedures and therapeutic options 
A deluge of bio-medical journals confronts the worker in medicine and biology. Nobody is capable of reading the papers of interest to him in his own language, let alone the mass of international scientific production. Why then, another new journal?

The reason is simply that, as with a poor consumer looking for a new family car fulfilling his special wishes, the scientific author is confronted with an unsatisfying market of journals to which his special manuscript might be profitably submitted.

This is decidedly the case with respect to our field of interest, hormones and metabolic research. In the already existing international journals devoted to endocrinology and metabolism, the intervals between submission of manuscripts and their publication are too long to secure rapid distribution of new findings. The numerous Congresses and Symposia are of value only to those who find the time to participate. Moreover, most of the papers presented at such meetings are not listed in the "Current Lists of Medical Literature", and many valuable and interesting findings are registered in the literature only when published in an internationally accepted journal - which sometimes takes months or even years.

Therefore, the Editors and Co-Editors of the present Journal have worked out, together with the Publisher, a new system for the reviewing of manuscripts which will ensure the fastest possible decision on either the acceptance of a paper or its return to the author. This applies to "Original Papers".

The "Short-Communications" and "Stop-Press-Communications", on the other hand, are to be published within an even shorter period of time, as the Editors will waive the copyright for them, i.e. authors are free to have their material published later on in a more extended form in another channel of communication. It will then only be necessary to mention the initial publication in this journal. Moreover, the offset-printing technique has been accepted for the publication of these short notices.

By these means the Editorial Board, composed of internationally known workers in endocrinology, hopes to be able to satisfy, at least partially, the rapidly growing demand for communication in the fields of hormone and metabolic research.

It is the sincere hope of the Editorial Board and of the Publisher, that "Hormone and Metabolic Research" will improve communication between clinicians and scientists working in endocrinology and metabolism, facilitate exchange of information between different countries, and open a new channel for the acceptance of valuable contributions of the younger generation working in academic medicine. The degree of success of the new journal will show whether this hope was justified.

Rachmiel Levine, New York

Ernst F. Pfeiffer, Ulm

- Fig. 1 Editorial of the very first issue.

in Graves' disease and autoimmune thyroiditis, including a most recent special issue [16-24].

Open access, eFirst publications and digital author offprints also show the digital transformation in a globalized world.

We are grateful to all authors, reviewers, editors, members of the Editorial Board, publishers and production staff to have dedicated their time and expertise to help the journal over the past 50 years to become what it is now!

Sincerely,

Matthias Schott, MD, PhD

Stefan R. Bornstein, MD, PhD

Constantine A. Stratakis, MD, D(med)Sci

Editors-in-Chief

\section{References}

[1] Levine R, Pfeifer ER. Introduction. Horm Metab Res 1969; 1: 1

[2] Mourtzinis G, Ebrahimi A, Gustafsson H, Johannsson G, Manhem K. Aldosterone to renin ratio as a screening instrument for primary aldosteronism in a middle-aged population with atrial fibrillation. Horm Metab Res 2017; 49: 831-837

[3] Grytaas MA, Strømsøy SS, Rørvik JT, Arnes JB, Heie A, Arnesen T, Jørstad MD, Nedrebø BG, Jøssang DE, Jensen DK, Rørvik HD, Sagen JV, Mellgren G, Thordarson HB, Husebye ES, Løvås K. Clinical characteristics and long-term outcome of primary aldosteronism in a Norwegian population. Horm Metab Res 2017; 49: 838-846 
[4] Inoue K, Yamazaki Y, Tsurutani Y, Suematsu S, Sugisawa C, Saito ], Omura M, Sasano H, Nishikawa T. Evaluation of cortisol production in aldosterone-producing adenoma. Horm Metab Res 2017; 49: 847-853

[5] Buffolo F, Monticone S, Burrello ], Tetti M, Veglio F, Williams TA, Mulatero P. Is primary aldosteronism still largely unrecognized? Horm Metab Res 2017; 49: 908-914

[6] Stowasser M, Ahmed A, Guo Z, Wolley M, Ungerer J, McWhinney B, Poglitsch M, Gordon R. Can screening and confirmatory testing in the management of patients with primary aldosteronism be improved? Horm Metab Res 2017; 49: 915-921

[7] Lenders JW, Eisenhofer G, Reincke M. Subtyping of patients with primary aldosteronism: An update. Horm Metab Res 2017; 49: 922-928

[8] Naruse M, Umakoshi H, Tsuiki M, Yokomoto M, Tagami T, Tanabe A, Shimatsu $A$. The latest developments of functional molecular imaging in the diagnosis of primary aldosteronism. Horm Metab Res 2017; 49: 929-935

[9] Beuschlein F, Mulatero P, Asbach E, Monticone S, Catena C, Sechi LA, Stowasser M. The SPARTACUS trial: Controversies and unresolved issues. Horm Metab Res 2017; 49: 936-942

[10] Velema MS, de Nooijer AH, Burgers VW, Hermus AR, Timmers HJ, Lenders JW, Husson O, Deinum J. Health-related quality of life and mental health in primary aldosteronism: A systematic review. Horm Metab Res 2017; 49: 943-950

[11] Omata K, Tomlins SA, Rainey WE. Aldosterone-producing cell clusters in normal and pathological states. Horm Metab Res 2017; 49: 951-956

[12] Gomez-Sanchez CE, Kuppusamy M, Reincke M, Williams TA. Disordered CYP11B2 expression in primary aldosteronism. Horm Metab Res 2017; 49: 957-962

[13] Scholl UI. Unanswered questions in the genetic basis of primary aldosteronism. Horm Metab Res 2017; 49: 963-968

[14] Prejbisz A, Kołodziejczyk-Kruk S, Lenders JW, Januszewicz A. Primary aldosteronism and obstructive sleep apnea: Is this a bidirectional relationship? Horm Metab Res 2017; 49: 969-976
[15] Funder JW. Primary aldosteronism: The next five years. Horm Metab Res 2017; 49: 977-983

[16] Rapoport B, McLachlan SM. Reflections on thyroid autoimmunity: A personal overview from the past into the future. Horm Metab Res 2018; 50: 840-852

[17] Diana T, Olivo PD, Kahaly G]. Thyrotropin receptor blocking antibodies. Horm Metab Res 2018; 50: 853-862

[18] Pujol-Borrell R, Álvarez-Sierra D, Jaraquemada D, Marín-Sánchez A, Colobran R. Central tolerance mechanisms to TSHR in Graves' disease: Contributions to understand the genetic association. Horm Metab Res 2018; 50: 863-870

[19] Kotwal A, Stan M. Current and future treatments for Graves' disease and Graves' ophthalmopathy. Horm Metab Res 2018; 50: 871-886

[20] Marinò M, Dottore GR, Leo M, Marcocci C. Mechanistic pathways of selenium in the treatment of Graves' disease and Graves' orbitopathy. Horm Metab Res 2018; 50: 887-893

[21] Krause G, Marcinkowski P. Intervention strategies into glycoprotein hormone receptors for modulating (mal-)function, with special emphasis on the TSH receptor. Horm Metab Res 2018; 50: 894-907

[22] Williams DE, Le SN, Godlewska M, Hoke DE, Buckle AM. Thyroid peroxidase as an autoantigen in Hashimoto's disease: Structure, function, and antigenicity. Horm Metab Res 2018; 50: 908-921

[23] Nagayama Y. Thyroid autoimmunity and thyroid cancer - the pathogenic connection: A 2018 update. Horm Metab Res 2018; 50: 922-931

[24] Moshkelgosha S, Masetti G, Berchner-Pfannschmidt U, Verhasselt HL, Horstmann M, Diaz-Cano S, Noble A, Edelman B, Covelli D, Plummer S, Marchesi JR, Ludgate M, Biscarini F, Eckstein A, Banga JP. Gut microbiome in $\mathrm{BALB} / \mathrm{C}$ and $\mathrm{C} 5 \mathrm{BL} / 6$ ] mice undergoing experimental thyroid autoimmunity associate with differences in immunological responses and thyroid function. Horm Metab Res 2018; 50: 932-941 